\title{
Regular Surface Patterning of Peatlands: Confronting Theory with Field Data
}

\author{
Maarten B. Eppinga, ${ }^{1 *}$ Max Rietkerk, ${ }^{1}$ Wiebe Borren,${ }^{2}$ Elena D. Lapshina,${ }^{3}$ \\ Wladimir Bleuten, ${ }^{3,4}$ and Martin J. Wassen ${ }^{1}$
}

\begin{abstract}
${ }^{1}$ Department of Environmental Sciences, Copernicus Institute, Faculty of Geosciences, Utrecht University, P.O. Box 80115, Utrecht 3508 TC, The Netherlands; ${ }^{2}$ TNO Built Environment and Geosciences, Business Unit Soil and Groundwater, P.O. Box 80015, Utrecht 3508 TA, The Netherlands; ${ }^{3}$ Department of Environmental Dynamics and Global Climate Change, Yugra State University, ul. Chekhova 16, Khanty-Mansiysk 628012, Russia; ${ }^{4}$ Department of Physical Geography, Faculty of Geosciences, Utrecht University, P.O. Box 80115, Utrecht 3508 TC, The Netherlands
\end{abstract}

\begin{abstract}
Regular spatial patterns of sharply bounded ridges and hollows are frequently observed in peatlands and ask for an explanation in terms of underlying structuring processes. Simulation models suggest that spatial regularity of peatland patterns could be driven by an evapotranspiration-induced scale-dependent feedback (locally positive, longer-range negative) between ridge vegetation and nutrient availability. The sharp boundaries between ridges and hollows could be induced by a positive feedback between net rate of peat formation and acrotelm thickness. Theory also predicts how scale-dependent and positive feedbacks drive underlying patterns in nutrients, hydrology, and hydrochemistry, but these predictions have not yet been tested empirically. The aim of this study was to provide an empirical test for the theoretical predictions; therefore, we measured underlying patterns in nutrients, hydrology, and hydrochemistry across a maze-patterned peatland in
\end{abstract}

\footnotetext{
Received 24 May 2007; accepted 3 March 2008; published online 3 April 2008

Electronic Supplementary Material: The online version of this article (doi:10.1007/s10021-008-9138-z) contains supplementary material, which is available to authorized users.

MR, EDL, and WBl planned the project. All authors together performed the fieldwork. MBE, WBo, and WBl analyzed data. MBE, MR, and MJW outlined the contents of the paper and wrote the first draft. WBo and WBI added hydrological data and WBl wrote additional material about hydrological measurements and results. MBE and MR finalized the manuscript.

*Corresponding author; e-mail: M.Eppinga@geo.uu.nl
}

the Great Vasyugan Bog, Siberia. The field data corroborated predicted patterns as induced by scaledependent feedback; nutrient concentrations were higher on ridges than in hollows. Moreover, diurnal dynamics in water table level clearly corresponded to evapotranspiration and showed that water levels in two ridges were lower than in the hollow in between. Also, the data on hydrochemistry suggested that evapotranspiration rates were higher on ridges. The bimodal frequency distribution in acrotelm thickness indicated sharp boundaries between ridges and hollows, supporting the occurrence of a positive feedback. Moreover, nutrient content in plant tissue was most strongly associated with acrotelm thickness, supporting the view that positive feedback further amplifies ridge-hollow differences in nutrient status. Our measurements are consistent with the hypothesis that the combination of scale-dependent and positive feedback induces peatland patterning.

Key words: surface patterns; self-organization; positive feedback; scale-dependent feedback; peatlands; Great Vasyugan Bog; Siberia.

\section{INTRODUCTION}

Spatial surface patterning is one of the most striking features of boreal peatland ecosystems, and a considerable amount of attention has been paid to 
this phenomenon in the peatland literature of the last century (Foster and others 1983; Charman 2002). Analysis of spatial peatland patterns provides a means for testing hypotheses about underlying structuring processes (Belyea and Lancaster 2002). The recently established view of peatlands as complex adaptive systems has emphasized the need for a better understanding of these structuring processes to predict the response of peatland ecosystems to external forcing such as global climate change (Levin 1998; Belyea and Malmer 2004; Belyea and Baird 2006; Eppinga and others in press).

A common feature of peatlands is the spatially irregular patterning of distinct microforms (hummocks and hollows, characteristic spatial scale $10^{1}-10^{2} \mathrm{~m}^{2}$, Belyea and Clymo 2001). Hummocks are elevated above hollows because hummocks have a thicker acrotelm, which is an aerobic layer consisting of active peat-forming vascular plants and mosses, together with slightly decomposed litter. Hollows have a much thinner acrotelm or no acrotelm at all. Below the acrotelm the watersaturated peat layer or catotelm is situated. This means that the acrotelm-catotelm boundary is determined by the seasonal minimum water table (for example, Holden and Burt 2003). The structuring process that could explain the formation of hummocks and hollows is a positive feedback between net rate of peat formation and acrotelm thickness on slightly elevated, dryer sites, mainly because of increased production of vascular plants (Wallén 1987; Wallén and others 1988; Belyea and Clymo 2001). Thus, slight differences between more densely vegetated dryer sites and more sparsely vegetated wetter sites may further amplify and lead to spatial patterning of sharply bounded microforms. From here we refer to this process as positive feedback.

Less common, but still frequently observed, are two types of regular spatial peatland patterning that occur on the mesotope scale $\left(10^{4}-10^{6} \mathrm{~m}^{2}\right.$, Sjörs 1983; Wallén and others 1988). The first type comprises merged hummocks forming linear strings alternating with lower and wetter hollows, oriented along the contours of mire slopes. On flat parts of mires the second type of regular patterning is observed; merged hummocks forming ridges that are star- or net-like, enclosed by lower and wetter hollows. This study focuses on the latter pattern, which is also referred to as maze patterns (Rietkerk and others 2004a).

In the Great Vasyugan Bog, Western Siberia, extensive areas with maze patterning occur (Rietkerk and others 2004a). Characteristic features of maze patterns are the spatial regularity and the sharp boundaries between different vegetation communities occupying ridges and hollows. Positive feedback alone cannot explain spatial regularity in peatland patterning (Rietkerk and others 2004a). Instead, recent modeling studies suggest that the spatial regularity of maze patterns could be induced by nutrient accumulation under ridges, which is driven by increased evapotranspiration rates by vascular plants (especially shrubs and trees) that grow on these ridges (Rietkerk and others 2004a). This structuring process would imply that because of higher evapotranspiration rates, there is a net flow of water and dissolved nutrients toward ridges. Subsequently, the nutrients become trapped on ridges through uptake by vascular plants. So, during their lifespan, vascular plants that grow on ridges accumulate nutrients originating from outside the ridge. Nutrients become available again through mineralization of vascular plant litter, but this only increases nutrient availability on the local scale (within the ridge). Models predict that this local recycling effect outweighs the effect of nutrient uptake, meaning that nutrient concentrations in the mire water under ridges also increase (Rietkerk and others 2004a; Eppinga and others in press; see on-line appendix A for details). Because higher nutrient availability will lead to an increase in vascular plant biomass, this is a selfreinforcing process. This self-reinforcing process has a positive effect on nutrient concentration and plant growth on the local scale (inside the ridge) but a negative effect on a longer range (outside the ridge). From here we refer to this process as scaledependent feedback. Although scale-dependent feedback provides an explanation for the spatial regularity of maze patterns, it cannot explain the sharp boundaries between ridges and hollows as observed in the field (Figure 1; Eppinga and others in press).

So, on the one hand positive feedback explains the distinct differentiation of the peatland surface into sharply bounded hummocks and hollows, but cannot explain spatial regularity (Table 1). On the other hand, scale-dependent feedback explains spatial regularity, but cannot explain the sharp boundaries between ridges and hollows (Table 1). Because maze patterns comprise both features, it has been suggested that positive and scale-dependent feedbacks may synergistically govern this type of spatial patterning in peatlands (Eppinga and others in press).

This hypothesis has mainly emerged from simulation modeling, but has not yet been tested empirically. The aim of the present study was to test whether underlying patterns in nutrients and hydrology corroborate the hypothesis that a com- 

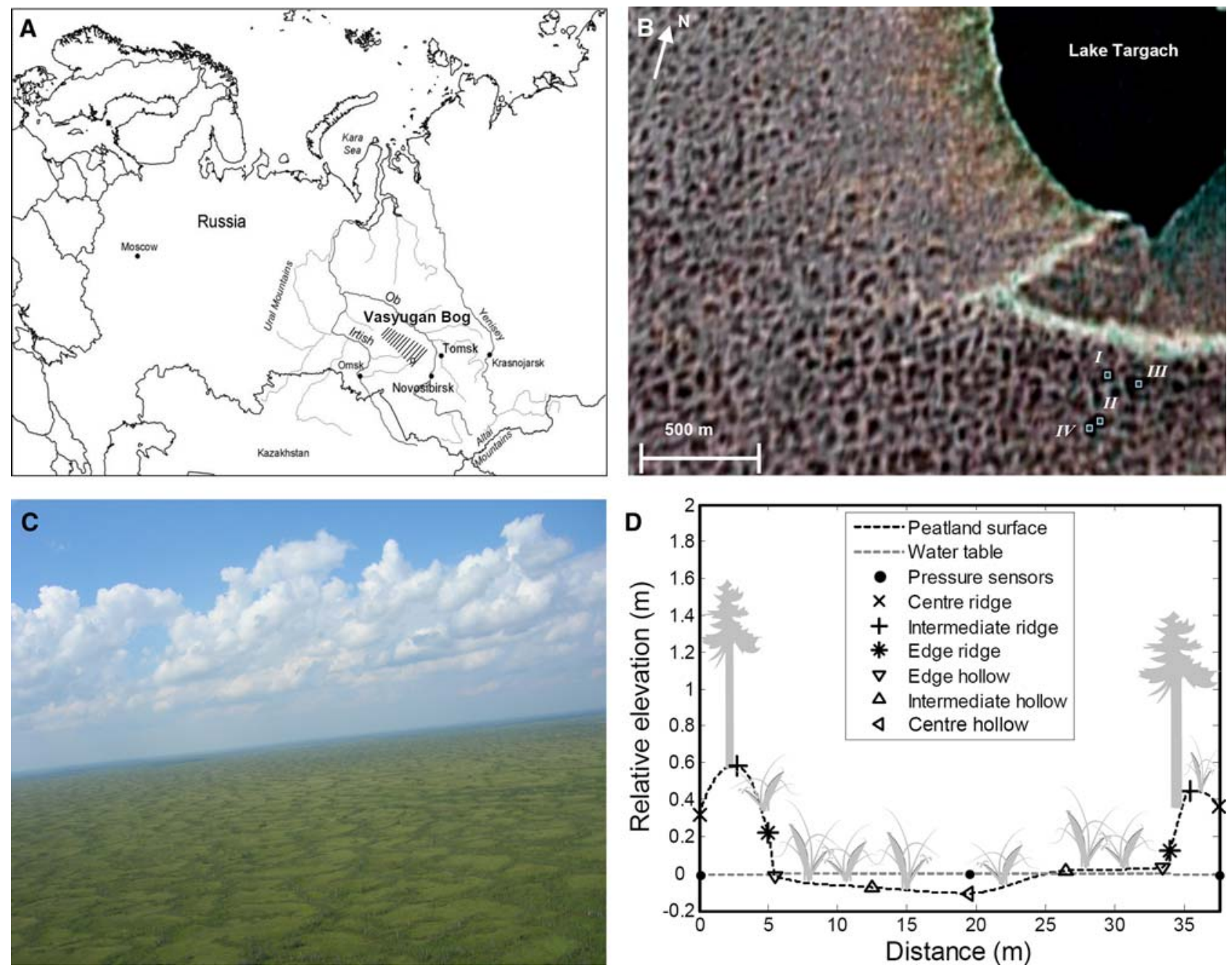

Figure 1. (A) Location of the Great Vasyugan Bog, Siberia, indicated by the hatched area. The circle within the hatched area indicates the study site, a maze-patterned plain. (B) Satellite image of the study site (accessed via Google Earth, coordinates: $56^{\circ} 16^{\prime} \mathrm{N}, 81^{\circ} 33^{\prime} \mathrm{E}$ ). Roman numerals indicate junctions of the orthogonal transects that were used in the sampling campaign. Hydrological measurements were also carried out along a large North-South (491 m) and East-West transect $(791 \mathrm{~m})$, which crossed at point I. (C) A photograph of the study site, taken from helicopter. (D) Cross-section of transect 1; a ridge-hollow-ridge sequence through the maze pattern. Markers indicate measured data (measured on July 28, 2005), whereas dashed lines are shape-preserving interpolations. Elevations are relative to the water level in the hollow (which is set at 0 ). Vegetation is included as an illustration.

bination of positive and scale-dependent feedback drives spatial surface patterning, using field data from a maze-patterned peatland. Previous models and other studies provide clear indications of how the maze pattern of ridges and hollows should be related to the associated underlying patterns in nutrients, hydrology, and hydrochemistry in case of the occurrence of the two types of feedbacks (see references in Table 1; on-line appendix A). Therefore, we measured nutrient concentrations in water and plant tissue and diurnal dynamics in water table level, and analyzed mire water chemistry across various transects through a maze-patterned peatland in the Great Vasyugan Bog. By comparing the measurements with the predictions (Table 1), it could then be inferred whether the combination of feedbacks is a likely explanation for maze patterning.

Previous studies suggest that the scale-dependent feedback induces a lower water table level under ridges than in hollows and, because of local recycling effects, higher nutrient concentration in mire water on ridges as compared to hollows (Table 1; on-line appendix A). Nutrient enrichment experi- 


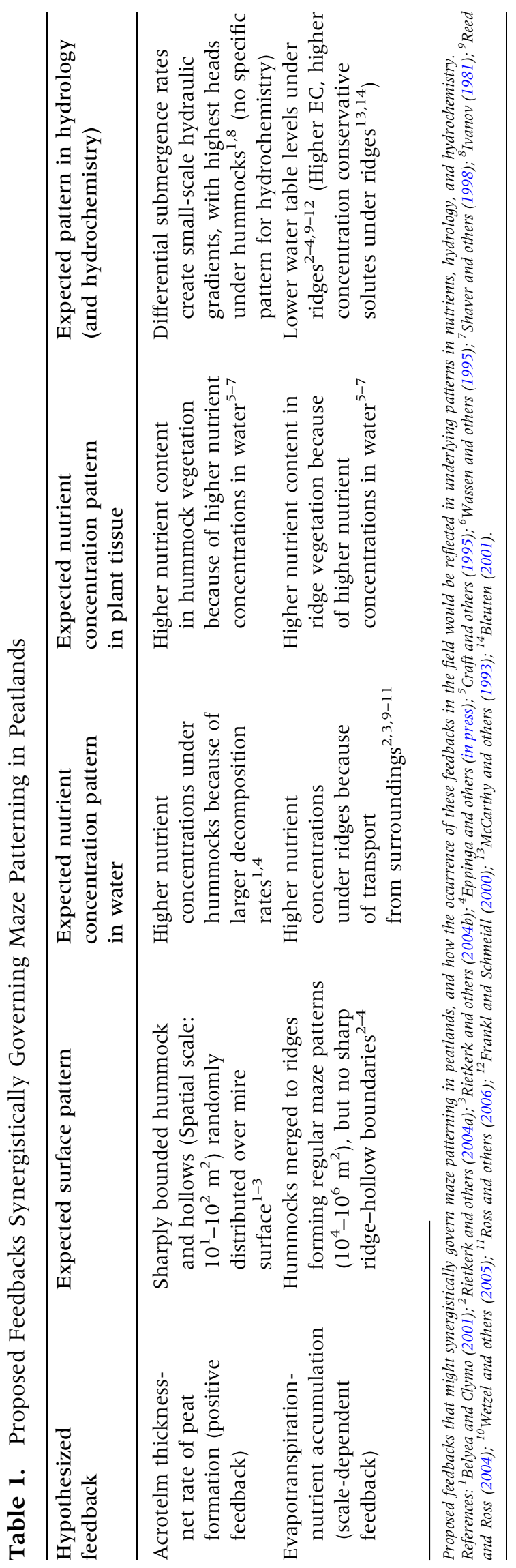

ments and correlation studies suggest that an increase in nutrient availability also increases nutrient content within plant tissue (Craft and others 1995; Wassen and others 1995; Shaver and others 1998). The scale-dependent feedback would further imply that higher evapotranspiration rates are reflected by both higher electrical conductivity and a higher concentration of conservative solutes (chloride, sodium) in the mire water under ridges as compared to hollows (Table 1).

The presence of the positive feedback would imply that cumulative decomposition (that is, the amount of mass decomposed within the entire acrotelm) increases with acrotelm thickness (Belyea and Clymo 2001). With increasing cumulative decomposition the nutrient availability on ridges is also expected to increase (on-line appendix A); so, the mire water under ridges would have a higher concentration of nutrients as compared to hollows, and therefore, the nutrient content of plant species may be higher when growing on ridges (Craft and others 1995; Wassen and others 1995; Shaver and others 1998). Also, the pressure on the peat at the acrotelm-catotelm boundary increases with acrotelm thickness. With higher pressure, this layer becomes more compressed and the effective pore space decreases (Ivanov 1981; Belyea and Clymo 2001). This means that for a given amount of water input, the water table rise will be larger in microforms with a thicker acrotelm (ridges). As a result, hydraulic gradients could develop that initiate a net water flux from ridges to hollows (Table 1). So, the scale-dependent feedback and the positive feedback would induce similar patterns in nutrient concentration in water and nutrient content of plant tissue, but lead to contradictory hypotheses on patterns in water table level (Table 1).

\section{Material and Methods}

\section{Study Site}

The Great Vasyugan Bog $\left(55-59^{\circ} \mathrm{N}, 76-83^{\circ} \mathrm{E}\right)$ is the largest undisturbed peat complex in the world, covering an area of more than $5 \times 10^{4} \mathrm{~km}^{2}$ (Lapshina and others 2001a). The area is situated at the water divide between the rivers $\mathrm{Ob}$ and Irtish, approximately $200 \mathrm{~km}$ northeast of Novosibirsk (Figure la). Permafrost disappeared in this region 11,000 years ago, and about 500 years later peat accumulation commenced on the sandy loam mineral subsoil (Lapshina and others $2001 \mathrm{~b})$. Current climate is typically continental, with a mean monthly temperature ranging 
between approximately $-20^{\circ} \mathrm{C}$ and approximately $+18^{\circ} \mathrm{C}$ (Semenova and Lapshina 2001). The frostfree period in this region lasts 100-120 days, which keeps the growing season relatively short (Semenova and Lapshina 2001). Contrary to most regions in the boreal zone, the precipitation excess is not very large: annual precipitation is $500 \mathrm{~mm}$, whereas the annual evapotranspiration is 300-500 mm (Semenova and Lapshina 2001). Within this area, the study was carried out on a maze-patterned plain $\left(56^{\circ} 16-56^{\circ} 20 \mathrm{~N}, 81^{\circ} 19-\right.$ $\left.81^{\circ} 36 \mathrm{E}\right)$, which was accessed by helicopter. Here the current thickness of the peat layer is 3-4 m. During the measurement period from July 28 to July 31, 2005, one precipitation event was recorded (on July 29). Averaged over two rain gauges (placed at $1.5 \mathrm{~m}$ above the mire surface, accuracy $0.1 \mathrm{~mm}$ ) rainfall measured $0.9 \mathrm{~mm}$. Mean temperature during this period at the Culym weather station $\left(55^{\circ} 08 \mathrm{~N} 80^{\circ} 58 \mathrm{E}\right.$; approximately $130 \mathrm{~km}$ from the study site) was $19.6^{\circ} \mathrm{C}$ with extreme temperatures ranging from $15.8^{\circ} \mathrm{C}$ to $25.0^{\circ} \mathrm{C}$.

The regularly patterned area comprises approximately $100 \mathrm{~km}^{2}$, and is clearly visible on satellite imagery (Figure lb) or from helicopter (Figure lc). Elevated ridges of widths ranging from 1 to $15 \mathrm{~m}$ form the maze-like structure. The depth of the acrotelm in these ridges is $0.1-0.7 \mathrm{~m}$. Vegetation on the lowest ridges is dominated by Betula nana, Typha latifolia, and Sphagnum obtusum, S. flexuosum, S. fallax, S. contortum, and S. majus. Higher ridges become dominated by B. pubescens, Carex lasiocarpa, C. elata ssp. omskiana, S. warnstorfii, and $S$. centrale. Vegetation at the highest ridges is characterized by Pinus sylvestris, Chamaedaphne calyculata, Ledum palustre, S. fuscum, S. magellanicum, S. russowii, S. capillifolium, and S. angustifolium. A previous study reports for bog ridges in other parts of southern Siberia an average aboveground density of dwarf shrubs and herbs of approximately $500 \mathrm{~g} \mathrm{~m}^{-2}$ (Vasiliev and others 2001). In our study site, aboveground vascular plant biomass also includes trees. The ridges are embedded in a matrix of waterlogged hollows that have no acrotelm. The width of the hollows ranges from 25 to $100 \mathrm{~m}$. The vegetation in these hollows is dominated by C. lasiocarpa, at an average density of approximately $170 \mathrm{~g} \mathrm{~m}^{-2}$. Other species that frequently occur in hollows were C. elata ssp. omskiana, Menyanthes trifoliata, Equisetum fluviatile, and the brown mosses Scorpidium scorpioides and Campylium polygamum. C. lasiocarpa is the only vascular plant species that is present in hollows and on all types of ridges.

\section{Field Measurements and Laboratory Analyses}

Field measurements were taken along four pairs of two orthogonal transects through the surface pattern. A transect ranged from the middle of one ridge to the middle of the next ridge, so each transect contained the halves of two ridges and the hollow in between. The average transect length was $42 \pm 12 \mathrm{~m}$. The two orthogonal transects crossed in the center of the hollow (centers are marked with I-IV in Figure $1 \mathrm{~b}$ ). On each ridge, three measurement points were selected: the center of the ridge, the edge of the ridge, and a point in between these two (referred to as "intermediate"). The hollow in between these ridges was sampled on five points: the center, the edges along the two ridges, and a point in between the center and each edge ("intermediate" class). Hence, one transect consisted of 3 ridge +5 hollow +3 ridge $=11$ measurement points. Because the center of the hollow was part of both orthogonal transects, the total number of measurement points for a pair of transects was 21. So in total, this would add up to $4 \times 21=84$ measurement points. However, one of the ridges in the survey was too narrow to perform three measurements; therefore two measurement points were chosen instead (so $n_{\text {ridge }}=47, n_{\text {hollow }}=36$, $n_{\text {total }}=83$ ).

In the first transect, diurnal dynamics in water table level were measured at three points in a North-South transect, containing two ridges and the hollow in between. The position of the center of this hollow is indicated with I in Figure $1 \mathrm{~b}$. The total length of this three point transect was $37.5 \mathrm{~m}$ (Figure ld). At each point, water level dynamics were recorded with water pressure sensors (air pressure compensated Keller: accuracy $0.1 \mathrm{~mm}$ ).

To have access to the mire water under ridges at the other measurement points, piezometers $(0.3 \mathrm{~m})$ were installed in small excavations. The piezometer mantles were covered with a filter (Eijkelkamp Agrisearch Equipment, The Netherlands). From these wells, water samples were taken and also distance to the mire surface was determined (see below). Because the water level in the hollows was at the mire surface, installing piezometers was not necessary for these measurement points.

On each measurement point we measured $\mathrm{pH}$ (WTW-pH96 with Ag/AgCl electrode), electrical conductivity $\left(\mathrm{EC}_{25}\right)$, and temperature (WTWLF91) directly in the mire water (compare Wassen and Joosten 1996). Alkalinity $\left(\left[\mathrm{HCO}_{3}^{-}\right]\right)$of the mire water was determined through acidimetric 
titration (Aquamerck alkalinity field set). We also determined the distance between the mire surface level and the water table (DWT). We measured the height where the hollow surface was strong enough to carry the probe of a sounding device, and this height was taken as the surface level. Within ridges, the water level was measured with the sounding device, and subsequently DWT was determined by eye, using the depth scale of the sounding device. The surface of the mire showed small-scale variability; so, DWT was determined by the average value of this distance for three randomly selected points within a $0.5-\mathrm{m}$ radius of the measurement point. The yearly minimum water level in this area is most often reached in August (Semenova and Lapshina 2001). Because the measurements took place at the last days of July, we think that DWT was close to the yearly lowest water table and therefore an appropriate estimate for the thickness of the acrotelm of the ridges.

At each measurement point a mire water sample was taken for laboratory analyses. Water samples were stored in polyethylene tubes that were rinsed with mire water. Within $8 \mathrm{~h}$, half of each water sample was acidified with $5 \mathrm{M} \mathrm{HNO}_{3}(0.025 \mathrm{ml}$ $\left.\mathrm{ml}^{-1}\right)$, the other half with $5 \mathrm{M} \mathrm{H}_{2} \mathrm{SO}_{4}(0.025 \mathrm{ml}$ $\mathrm{ml}^{-1}$ ). After centrifugation in the laboratory, the $\mathrm{HNO}_{3}$-acidified samples were analyzed using an Inductively Coupled Plasma technique (ICP-OES), and the $\mathrm{H}_{2} \mathrm{SO}_{4}$-acidified water samples were analyzed for major ions using colorimetric titration (Auto-Analyzer). Inorganic nitrogen concentrations were calculated as $\mathrm{N}_{\text {inorganic }}=\mathrm{N}\left[\mathrm{NO}_{3}^{-}+\mathrm{NH}_{4}^{+}\right]$.

Furthermore, around each measurement point we harvested 10 healthy-looking shoots of C. lasiocarpa, the only vascular plant species that was present on all ridges and in hollows. In the laboratory, samples were dried for 1 week at $70^{\circ} \mathrm{C}$, weighed, and ground. A subsample of 5-10 mg was used to determine carbon (C) and nitrogen (N) concentrations in the tissue, using a Dynamic Flash Combustion technique. Another subsample of approximately $125 \mathrm{mg}$ was taken and digested in $2.5 \mathrm{ml}$ of mixed acid consisting of $12.0 \mathrm{M} \mathrm{HClO}_{4}$ and $14.5 \mathrm{M} \mathrm{HNO}_{3}$ (mixing ratio 3:2), and $2.5 \mathrm{ml}$ of 27.3 M HF. Then, the samples were kept in closed Teflon jars at $90^{\circ} \mathrm{C}$ for $12 \mathrm{~h}$. Afterward the lids were removed and the jars were heated to $160^{\circ} \mathrm{C}$ for $8 \mathrm{~h}$. Subsequently $25 \mathrm{ml}$ of $1.0 \mathrm{M} \mathrm{HNO}_{3}$ was added, and the jars were closed again and kept at $90^{\circ} \mathrm{C}$ for $18 \mathrm{~h}$. The remaining solution was then used to determine phosphorus (P) and potassium (K) content of the plant tissue using the ICP-OES technique mentioned above.
The type of nutrient limitation was subsequently determined with a method based on $\mathrm{N}: \mathrm{P}, \mathrm{N}: \mathrm{K}$, and $\mathrm{K}: \mathrm{P}$ ratio in the plant tissue (Wassen and others 2005). Critical values for these ratios were derived in Wassen and others (2005); N:P ratio $>16$ determines P-limitation, $\mathrm{N}: \mathrm{P}$ ratios $<13.5$ indicate $\mathrm{N}$-limitation, and values in between, $\mathrm{N}$ and $\mathrm{P}$ co-limitation. N/P co-limitation means that there is no clear limitation either by $\mathrm{N}$ or $\mathrm{P}$ alone. (Co)limitation by $\mathrm{K}$ occurs at $\mathrm{N}: \mathrm{K}$ ratios $>2.1$ or $\mathrm{K}: \mathrm{P}$ ratios $>3.4$ (Wassen and others 2005).

Water level measurements were also made on a larger spatial scale. Therefore the previously described North-South transect was extended both to the North and the South to a total transect length of $491 \mathrm{~m}$ (NS) and perpendicular to that (crossing point I in Figure $1 \mathrm{~b}$ ) an East-West oriented transect (EW) of $718 \mathrm{~m}$ length. The average wavelength of the pattern (measured as the length of a ridgehollow sequence) did not differ for the NS and EW directions (NS: $51 \pm 20 \mathrm{~m}, \mathrm{EW}: 57 \pm 17 \mathrm{~m}$, Oneway ANOVA: $\left.F_{1,19}=0.543 P=0.47\right)$. Gauges were placed in each hollow and in each ridge along the transects (26 gauges along the EW transect, 21 along the NS transect) for measurement of the water level in a $0.2-0.4 \mathrm{~m}$ deep pit with a ruler (accuracy: $1 \mathrm{~mm}$ ). Because this method is not as accurate as using water pressure sensors (that we used in small-scale transect 1), the large-scale transect data could only identify large-scale gradients, rather than quantifying water level differences between neighboring ridges and hollows. Gauge readings were made during 3 days (in the afternoon).

To evaluate the water level variation the water pressure sensors and gauges were tightly fixed to a 4-m-long PVC tube pounded in the mineral soil below the peat layers to secure the vertical position during the recording period. The relative elevations of gauges and sensors were determined once with a theodolite (Wild), the vertical position of which was stabilized by extending the tripod with three PVC rods $(2 \mathrm{~m})$ firmly pushed into the peat.

\section{Comparisons and Statistical Treatment}

First, we analyzed whether the surface pattern of our study site was indeed characterized by sharp boundaries between ridges and hollows. The occurrence of sharp boundaries between ridges and hollows would result in a distinct two-phase mosaic, whereas gradual transitions between ridges and hollows would result in a surface pattern in which intermediate phases also frequently occur (Eppinga and others in press). Hence, the sharpness 
of boundaries between ridges and hollows can be assessed by analysis of the frequency distribution of surface elements (vascular plant biomass or acrotelm thickness): occurrence of sharp boundaries would result in a bimodal frequency distribution of surface elements, whereas gradual transitions would result in a unimodal distribution around the mean value of the surface element examined. We used the DWT data as a measure of acrotelm thickness, and tested for bimodality by fitting to the data both a normal distribution function and a bimodal distribution function given by $P=q N[\mathrm{DWT}$, $\left.\mu_{1}, \sigma_{1}\right]+(1-q) N\left[\mathrm{DWT}, \mu_{2}, \sigma_{2}\right]$, where $q$ is a constant between 0 and 1 and $N$ is the normal distribution with mean $\mu$ and standard deviation $\sigma$. Distributions were fitted using the maximum likelihood method (Sokal and Rohlf 1995). Significance of the bimodal distribution as compared to the unimodal model was determined by the loglikelihood ratio (Van de Koppel and others 2001). For this analysis of the DWT data we used R Project software (Version 2.3.0, R Development Core Team 2006).

For nutrient concentrations and other characteristics of the mire water and for nutrient content of the plant tissue (C. lasiocarpa), we first tested for general differences between ridges and hollows. Also, we analyzed the spatial trend through the peatland surface pattern, using an ordinal scale of six classes ranging from the ridge-center to hollowcenter. Subsequently, we used electrical conductivity and, in the absence of detectable chloride concentrations, the conservative solute sodium (compare McCarthy and others 1993) in the mire water as indicators for evapotranspiration rates. Sodium concentration of the mire water is a suitable indicator for evapotranspiration rate because adsorption processes usually do not influence it, and the amount of sodium uptake by plants is small (McCarthy and others 1993; Bleuten 2001).

Further statistical analyses were done with the software SPSS (Version 11.0.1, SPSS Inc. 2001). For all comparisons, homogeneity of variances between groups was tested with the Levene test statistic. If variances were homoscedastic at the $\alpha=0.05$ significance level, differences were tested with oneway ANOVA, and in case of more than two groups a Post Hoc Tukey HSD-test was also carried out. Otherwise we turned to the nonparametric MannWhitney $U$ test, and in case of more than two groups we performed pairwise Mann-Whitney $U$ tests, and subsequently performed a Bonferroni adjustment.

To reveal the correlation structure in the dataset, we performed a Principal Component Analysis
(PCA) using Varimax rotation. For this PCA, the hydrochemistry variables and the nutrient variables measured in plant tissue were tested for skewness. If |skewness $\mid>1$ for a certain variable, it was log-transformed to approximate a normal distribution. Subsequently, all variables were standardized to zero mean and unit variance. The scores for each measurement point on the components extracted with the PCA were obtained using regression.

\section{RESUlTS}

\section{Sharpness of Boundaries Within the Surface Pattern}

The Distance to the Water Table data (DWT, indicating acrotelm thickness) showed a bimodal distribution (Figure 2; $\chi^{2}=147.307$, degrees of freedom $=3, P<0.001)$. Observations were either close to a positive acrotelm thickness around $0.43 \mathrm{~m}$, which is the ridge state, or close to a negative acrotelm thickness (meaning that the water table was above the peatland surface) around

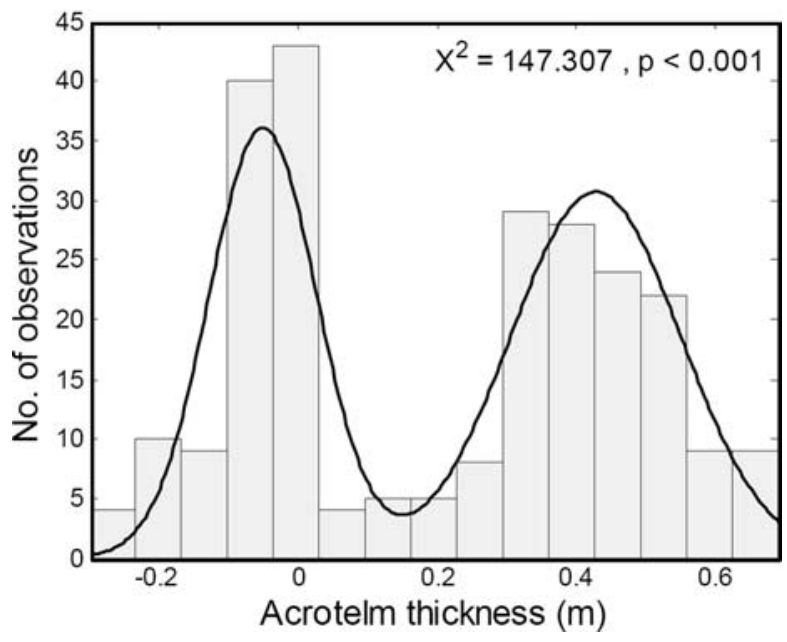

Figure 2. Gray bars show the frequency distribution of measured acrotelm thickness across a maze-patterned plain in the Great Vasyugan Bog, Siberia. Note that negative values of acrotelm thickness indicate that the water table was above the peatland surface. The full black line shows a bimodal fit of the form $P=q N[\mathrm{DWT}$, $\left.\mu_{1}, \sigma_{1}\right]+(1-q) N\left[\mathrm{DWT}, \mu_{2}, \sigma_{2}\right]$, where $q$ is a constant between 0 and 1 and $N$ is the normal distribution with mean $\mu$ and standard deviation $\sigma$. (Parameter values: $\left.q=0.43, \mu_{1}=-0.05, \quad \sigma_{1}=0.08, \quad \mu_{2}=0.43, \quad \sigma_{2}=0.12\right)$ Significance of the bimodal distribution as compared to the unimodal model was determined by the log-likelihood ratio. The bimodal distribution of acrotelm thickness indicates sharp transitions between ridges and hollows within the surface pattern. 
Table 2. Differences of Water and Vegetation Characteristics between Ridges and Hollows

\begin{tabular}{lccrr}
\hline Variable & Ridge $(n=47)$ & Hollow $(n=36)$ & Test statistic & $P$-value \\
\hline Water $\left(\mathrm{mg} \mathrm{l}^{-1}\right)$ & & & & \\
DWT $(\mathrm{cm})$ & $41(13)$ & $-7(6)$ & $U<0.001$ & $<0.001$ \\
$\mathrm{pH}(-)$ & $4.93(0.83)$ & $5.64(0.36)$ & $U=344$ & $<0.001$ \\
$\mathrm{HCO}_{3}\left(\mathrm{mmol} \mathrm{l}^{-1}\right)$ & $0.25(0.16)$ & $0.34(0.08)$ & $U=599$ & 0.017 \\
$\mathrm{EC}\left(\mu \mathrm{cm}^{-1}\right)$ & $53(14)$ & $48(8)$ & $U=632$ & 0.049 \\
Temperature $\left({ }^{\circ} \mathrm{C}\right)$ & $16.76(3.17)$ & $21.63(2.24)$ & $U=171$ & $<0.001$ \\
$\mathrm{~N}_{\text {inorg }}$ & $1.38(0.34)$ & $1.03(0.17)$ & $U=247$ & $<0.001$ \\
$\mathrm{P}$ & $0.29(0.16)$ & $0.10(0.04)$ & $U=67$ & $<0.001$ \\
$\mathrm{Al}$ & $0.26(0.15)$ & $0.06(0.03)$ & $U=41$ & 0.001 \\
$\mathrm{Ca}$ & $6.15(2.03)$ & $5.39(0.88)$ & $U=483$ & $<0.001$ \\
$\mathrm{Fe}$ & $0.72(0.48)$ & $0.29(0.12)$ & $U=106$ & $<0.001$ \\
$\mathrm{~K}$ & $1.23(0.76)$ & $0.46(0.59)$ & $F_{1,81}=25$ & $<0.001$ \\
$\mathrm{Mg}$ & $2.77(0.56)$ & $2.32(0.29)$ & $U=377$ & 0.001 \\
$\mathrm{Mn}$ & $0.33(0.36)$ & $0.11(0.08)$ & $U=264$ & $<0.001$ \\
$\mathrm{Na}$ & $1.55(0.32)$ & $1.35(0.28)$ & $F_{1,81}=8.7$ & $<0.001$ \\
$\mathrm{~S}$ & $1.13(0.15)$ & $0.96(0.09)$ & $U=302$ & \\
$\mathrm{Si}$ & $1.62(0.76)$ & $0.85(0.14)$ & $U=104$ & $<0.001$ \\
Vegetation $\left(\mathrm{mg} \mathrm{g}^{-1}\right)$ & & & & $<0.001$ \\
$\mathrm{P}$ & $1.05(0.25)$ & $0.60(0.12)$ & $U=33$ & $<0.001$ \\
$\mathrm{~N}$ & $16.49(2.29)$ & $11.05(1.11)$ & $U=35$ & 0.047 \\
$\mathrm{~K}$ & $1.18(2.45)$ & $8.89(0.96)$ & $U=176$ & \\
$\mathrm{C}$ & $454(19)$ & $462(18)$ & $F_{1,81}=4.1$ & \\
\end{tabular}

Measured values of water and vegetation variables on ridges and hollows of a maze-patterned plain in the Great Vasyugan Bog, Siberia.

$-0.05 \mathrm{~m}$, which is the hollow state. Despite the fact that edges of ridges and hollows were strongly represented in the dataset ( 31 out of 83 measurement points; 93 out of 249 DWT observations), the data contained relatively few observations of intermediate acrotelm thickness (Figure 2). This bimodality in the frequency distribution of acrotelm thickness corroborates the occurrence of sharp boundaries between ridges and hollows.

\section{Patterns in Nutrients}

Concentrations of nitrogen $(\mathrm{N})$, phosphorus $(\mathrm{P})$, and potassium $(\mathrm{K})$ were higher in mire water under ridges than in hollows (Table 2). P concentrations showed the largest difference between ridges and hollows. Observing the spatial trend, there was a sharp decrease in $\mathrm{N}, \mathrm{P}$, and $\mathrm{K}$ concentrations at the ridge-hollow interface (Figure 3 ).

Both $\mathrm{N}$ and $\mathrm{P}$ content were higher in C. lasiocarpa shoots growing on ridges (Table 2). N:P ratios revealed that plant growth in the hollows was N/P co-limited at the edge of the hollows, and P-limited at larger distances from the ridge (Figure 3). Growth on the ridges was N/P co-limited (Figure 3). For $P$, there was a significant decline in tissue content within the ridge (from the center to the edge, Figure 3). For both $\mathrm{N}$ and $\mathrm{P}$, there was a sharp decrease in tissue content at the ridge-hollow interface. $\mathrm{P}$ content was higher at the edge of the hollow as compared to the intermediate hollow class, which led to a similar N:P ratio on the edge of the hollow as compared to the ridge vegetation (but both $\mathrm{N}$ and $\mathrm{P}$ content were lower at the edge of the hollow as compared to the ridge). Analysis of the $\mathrm{N}: \mathrm{K}$ and $\mathrm{P}: \mathrm{K}$ ratios in the plant tissue revealed that growth was not (co)-limited by K.

\section{Patterns in Hydrology}

In the three-point transect, recorded water levels in both ridges were consistently lower than in the hollow (on average $5 \mathrm{~mm}$, Figure 4). The diurnal vertical dynamics in water level of both the hollow and the ridges corresponded to evapotranspiration, which was greatly reduced or ceased close to sunset (Figure 4). The average evapotranspiration rate on ridges was estimated to be $9.1 \pm 2.3 \mathrm{~mm} \mathrm{~d}^{-1}$ (see on-line Appendix B for calculations and further analyses of diurnal water table dynamics). Close to sunset, the daytime evapotranspiration was first replenished in the hollow (Figure 4). During the night, there was a consistent rise of the water table in both ridges by advection from the hollow into the ridges (Figure 4). The potential influxes of the main limiting nutrients into ridges were estimated 


\section{Water}
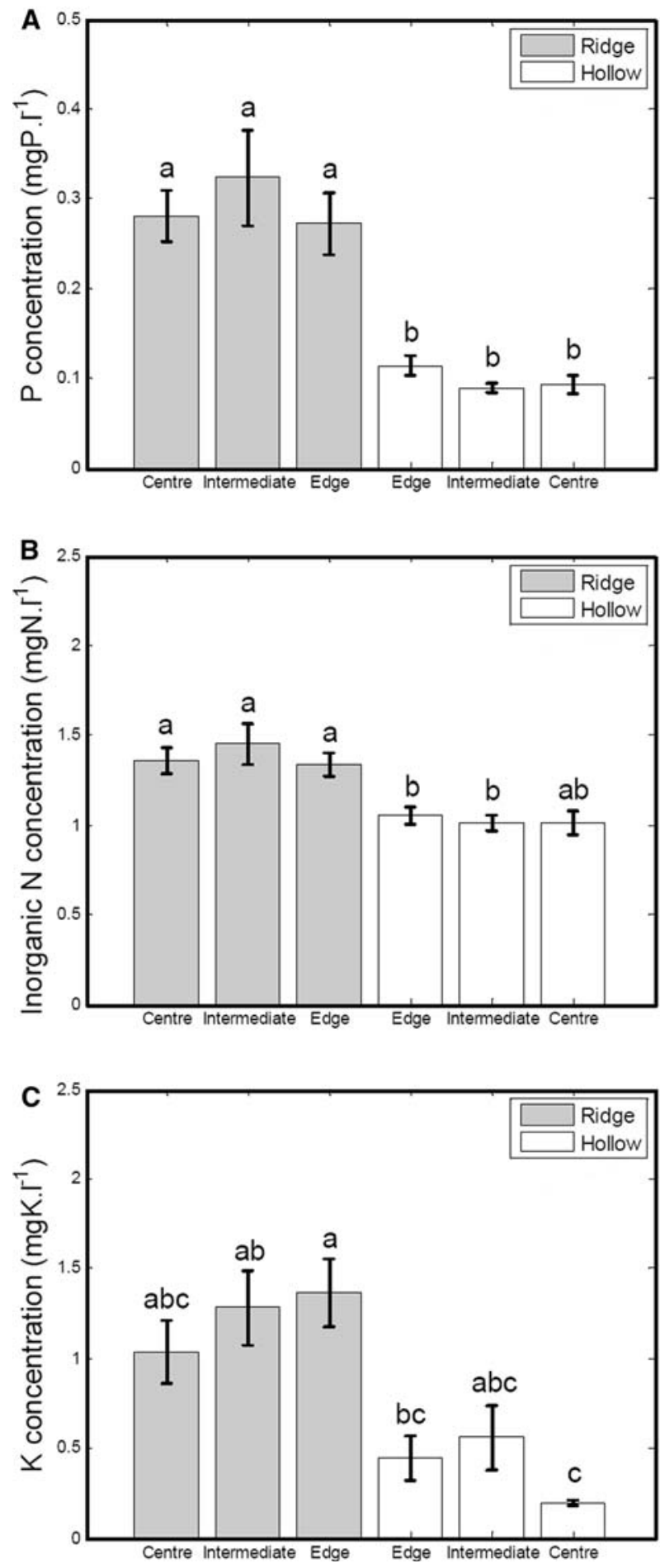

to be $0.7 \pm 0.3 \mathrm{mgP} \quad \mathrm{m}^{-2}$ ridge $\mathrm{d}^{-1}$ and $6.9 \pm$ $2.6 \mathrm{mgN} \mathrm{m}^{-2}$ ridge $\mathrm{d}^{-1}$ (on-line appendix B).

The trend of the head gradient in the EW direction was almost constant over time $\left(262 \times 10^{-7}\right)$, indicating a steady flow in a western
Vegetation
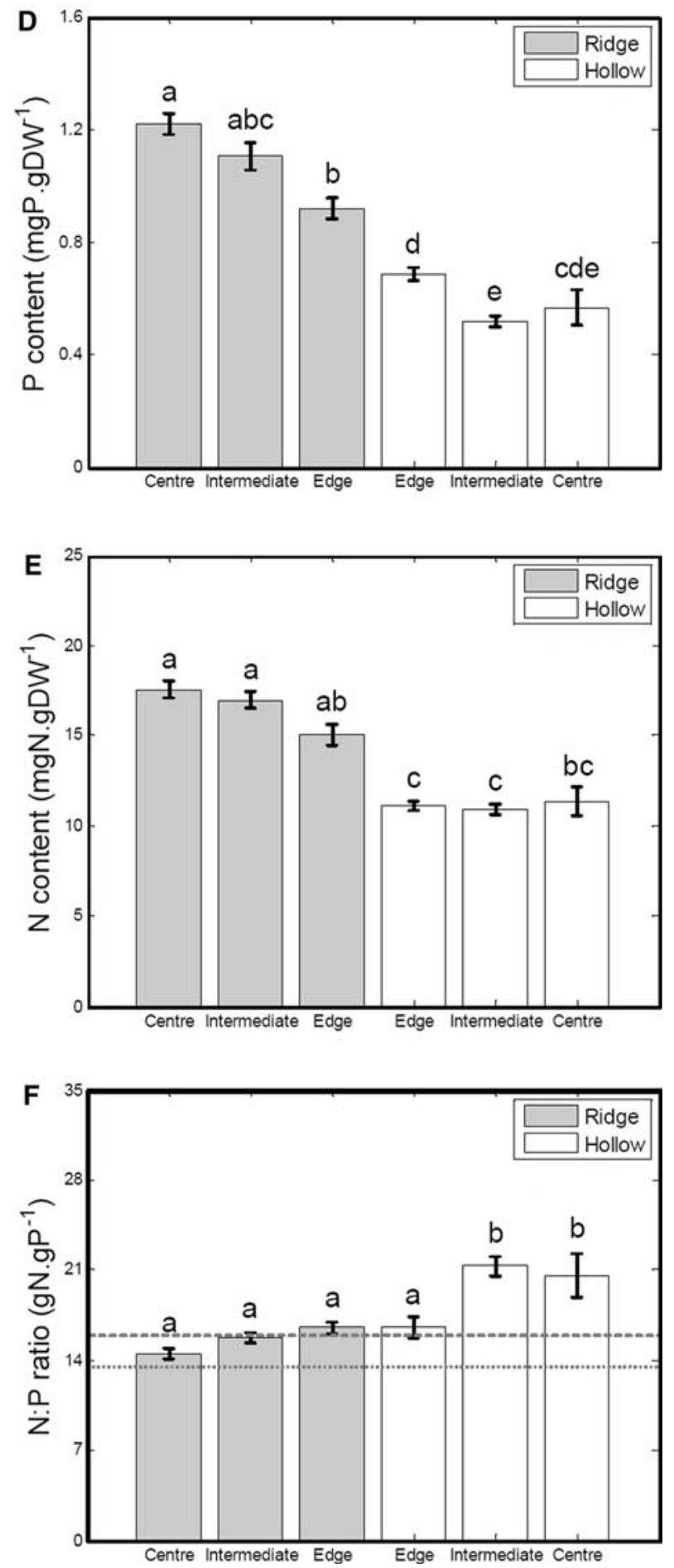

direction (Figure 5). With a hydraulic conductivity of the 'plant layer' (that is, the active plant and litter layer in the hollows) of $548 \mathrm{~m} \mathrm{~d}^{-1}$ (Borren and Bleuten 2006) and thickness of the 'plant layer' of $0.5 \mathrm{~m}$ the average westward water flux 
Figure 3. Nutrient concentrations measured in mire water and vegetation tissue (Carex lasiocarpa) of a mazepatterned plain in the Great Vasyugan Bog, Siberia. Error bars show \pm 1 standard error. Bars with the same letter do not differ at the $P=0.05$ level. (A) The spatial trend in mire water phosphorus concentration shows a sharp decline at the ridge-hollow interface. (B) Inorganic nitrogen concentration shows a similar pattern, but relative differences between ridges and hollows are smaller. (C) Potassium concentration shows high variation throughout the pattern, but a sharp decline in concentration at the ridge-hollow interface similar to phosphorous and inorganic nitrogen. (D) The spatial trend in phosphorous content of the vegetation tissue reveals a significant difference between the center and the edge of the ridges. (E) The spatial trend in nitrogen reveals a similar pattern as phosphorus content. (F) Nutrient ratios in the plant tissue show that the ridge and the edge of the hollow are N/P co-limited, the intermediate and center hollow classes are P-limited. Above the dashed line $(\mathrm{N}: \mathrm{P}=16)$, plant growth is $\mathrm{P}$ limited. Below the dotted line $(\mathrm{N}: \mathrm{P}=13.5)$, plant growth is $\mathrm{N}$ limited. In between the dotted and the dashed line, N/P co-limitation occurs.

was approximately $0.007 \mathrm{~m}^{3} \mathrm{~d}^{-1} \mathrm{~m}^{-1}$ across the flow direction. The hydraulic gradient in the EW direction was not smooth. Water level jumps seemed to occur at several points along the EW transect, coinciding with the occurrence of ridges (Figure 5). This may indicate that water was dammed up at the ridges because of their lower hydraulic conductivity as compared to hollows (for example, Swanson and Grigal 1988; Couwenberg and Joosten 2005). It is important to note, however, that the precision of our measurements on the large-scale transects was not high enough to confirm water ponding in front of ridges. The gradient in NS direction was much smaller, decreasing in three days from $53 \times 10^{-7}$ to $42 \times 10^{-7}$ (data not shown), but this gradient was too small to enable conclusions about the general direction of water flow in NS direction.

\section{Patterns in Hydrochemistry}

The hydrochemistry of the mire water under ridges significantly differed from that under hollows (Table 2). In general mire water under ridges was characterized by a lower $\mathrm{pH}$, temperature, and alkalinity and higher concentrations of the solutes examined (Table 2). Also the indicators for evapotranspiration rates, electrical conductivity (EC) and sodium $(\mathrm{Na})$, were higher in the mire water under ridges than in hollows (Table 2 ).

\section{Correlation Structure}

The Principal Component Analysis revealed four components, which together explained more than $75 \%$ of the variance in the data (Table 3 ). The first component (indicated I in Table 3, explaining $29.3 \%$ of the total variance) showed that higher nutrient concentrations in the plant tissue were associated with larger DWT, lower temperature,

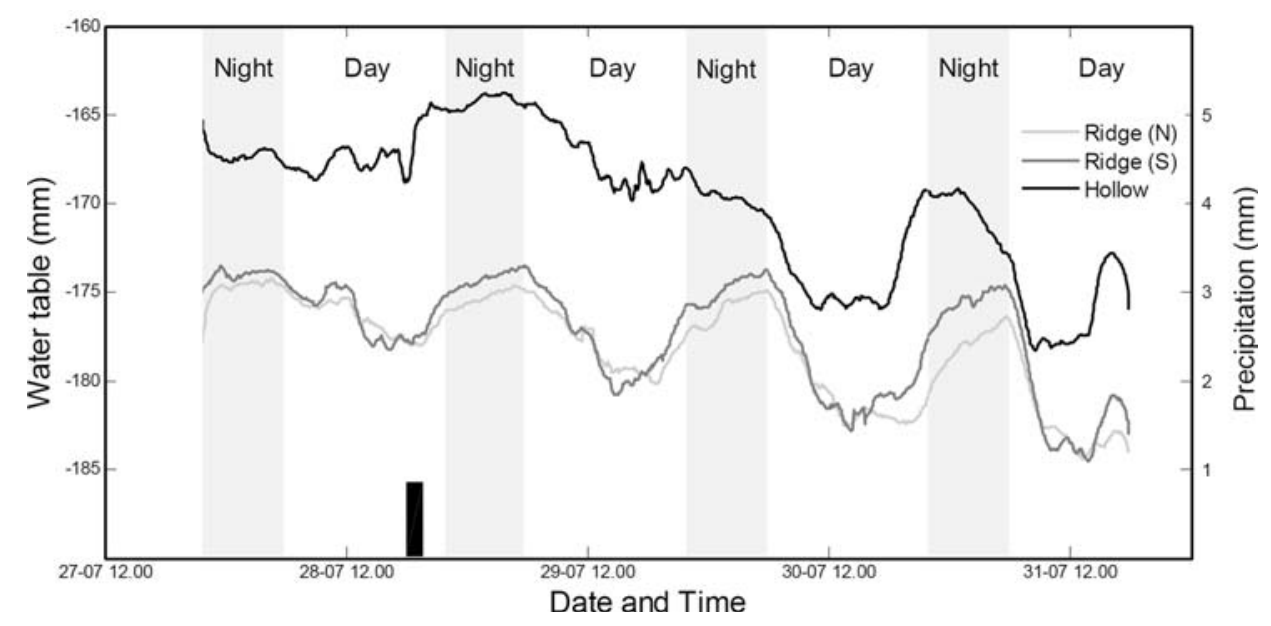

Figure 4. Diurnal dynamics in water table level for the two ridges and the hollow in between, situated in a mazepatterned peatland in the Great Vasyugan Bog, Siberia. Water levels are measured relative to an arbitrary reference height. Gray areas show the period between sunset and sunrise (data from the Culym weather station). The higher water table in hollows indicates a continuous water flow toward the ridges. During the day inflow into the ridges is overcompensated by evapotranspiration losses. The transect is oriented in a north-south direction. The distance between the northern $(\mathrm{N})$ and southern (S) ridge is $37.5 \mathrm{~m}$. The hollow measurement point is indicated as point I in Figure $1 \mathrm{~b}$. The black bar indicates the occurrence of the only precipitation event $(0.9 \mathrm{~mm})$ during the study period. 
lower alkalinity, and lower $\mathrm{pH}$, the latter four variables corresponding to the hollow-ridge gradient. The second component (explaining $21.3 \%$ of the total variance) revealed that concentrations of the nutrients $\mathrm{N}, \mathrm{P}$, and $\mathrm{K}$ in the mire water were positively correlated with each other and also with other ions, including the conservative solute Na. The third component (explaining 13.3\% of the total variance) indicated that in the dataset, higher concentrations of the base cations $\mathrm{Ca}$ and $\mathrm{Mg}$ were positively correlated with each other, and also with Mn concentration in the mire water. Finally, the

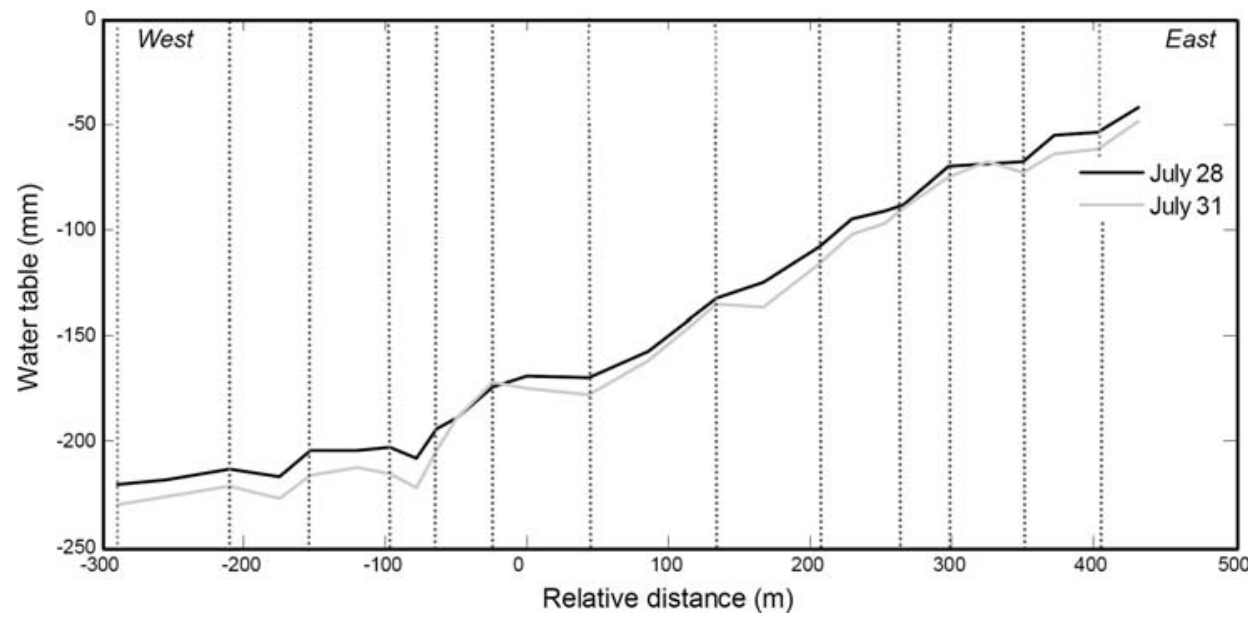

Figure 5. Measured water table level in a 791-m-long transect through a maze-patterned peatland in the Vasyugan Bog, Siberia. Distance $=0$ corresponds with point I in Figure lb. The transect is oriented in an east-west direction. The vertical dotted lines indicate the occurrence of ridges. The small head gradient $\left(262 \times 10^{-7}\right)$ indicates water flow in a westward direction. This head gradient was fairly constant during the measurement period (28-31 July 2005).

Table 3. Correlation Structure in Water and Vegetation Variables using Principal Component Analysis

\begin{tabular}{|c|c|c|c|c|}
\hline Variable & I & II & III & IV \\
\hline Cumulative variance explained (\%) & 29.3 & 50.6 & 63.9 & 76.4 \\
\hline $\mathrm{N}_{\mathrm{veg}}$ & 0.84 & 0.35 & 0.10 & -0.03 \\
\hline$P_{\text {veg }}$ & 0.83 & 0.32 & 0.19 & 0.21 \\
\hline DWT & 0.82 & 0.35 & 0.27 & 0.03 \\
\hline Temperature $\left({ }^{\circ} \mathrm{C}\right)_{\mathrm{aq}}$ & -0.81 & -0.21 & -0.01 & -0.33 \\
\hline $\mathrm{pH}_{\mathrm{aq}}$ & -0.72 & -0.13 & 0.32 & -0.22 \\
\hline $\mathrm{K}_{\mathrm{veg}}$ & 0.68 & 0.29 & 0.07 & 0.32 \\
\hline $\mathrm{Al}_{\mathrm{aq}}$ & 0.64 & 0.54 & 0.31 & 0.15 \\
\hline $\mathrm{HCO}_{3 \mathrm{aq}}$ & -0.63 & -0.09 & 0.53 & -0.11 \\
\hline $\mathrm{Si}_{\mathrm{aq}}$ & 0.61 & 0.46 & 0.02 & 0.47 \\
\hline $\mathrm{K}_{\mathrm{aq}}$ & 0.26 & 0.84 & 0.14 & 0.07 \\
\hline $\mathrm{Na}_{\mathrm{aq}}$ & 0.16 & 0.72 & -0.15 & 0.35 \\
\hline $\mathrm{N}_{\mathrm{aq}}$ & 0.33 & 0.72 & 0.14 & 0.03 \\
\hline $\mathrm{P}_{\mathrm{aq}}$ & 0.56 & 0.71 & 0.18 & 0.10 \\
\hline $\mathrm{Fe}_{\mathrm{aq}}$ & 0.34 & 0.61 & 0.50 & -0.23 \\
\hline $\mathrm{Ca}_{\mathrm{aq}}$ & -0.10 & 0.08 & 0.91 & 0.13 \\
\hline $\mathrm{Mn}_{\mathrm{aq}}$ & 0.23 & 0.52 & 0.65 & -0.14 \\
\hline $\mathrm{Mg}_{\mathrm{aq}}$ & 0.35 & 0.11 & 0.65 & 0.46 \\
\hline $\mathrm{EC}_{\mathrm{aq}}$ & 0.11 & 0.18 & -0.05 & 0.81 \\
\hline $\mathrm{C}_{\mathrm{veg}}$ & -0.19 & 0.09 & -0.11 & -0.72 \\
\hline $\mathrm{S}_{\mathrm{aq}}$ & 0.32 & 0.56 & 0.11 & 0.59 \\
\hline
\end{tabular}

Correlation structure in variables measured in water and vegetation samples from a maze-patterned plain in the Great Vasyugan Bog, Siberia. For each variable, loadings on principal components (after Varimax rotation) are given. Highest eigenvector scores for each variable are depicted in bold. DWT means distance from the peatland surface to the water table. Values of the vegetation variables have subscript veg and are given in $\mathrm{mg}^{-1}$. Water variables have subscript aq and are depicted in mg $\mathrm{I}^{-1}$ unless indicated differently. Standard deviations are given between brackets. DWT means distance from the peatland surface to the water table. The F-statistic is presented for comparisons with one-way ANOVA, the U-statistic is presented for comparisons with the Mann-Whitney U-test. 


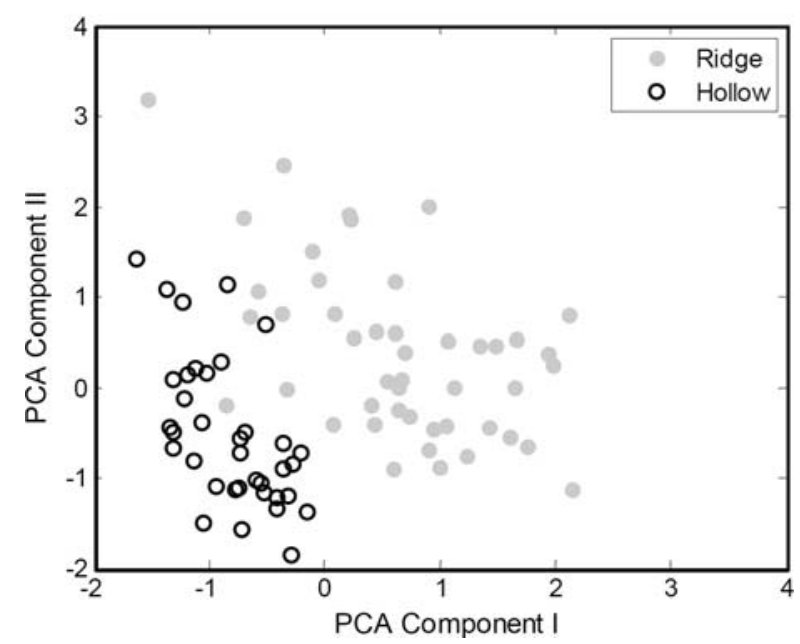

Figure 6. Results of a PCA (using Varimax rotation) of measurement points at ridges and hollows of a mazepatterned plain in the Great Vasyugan Bog, Siberia. The axes of the graph represent the first two components extracted with the PCA. Gray dots indicate ridges, black dots hollows. Ridges generally had higher scores on both components. The first component (reflecting a positive feedback between net rate of peat formation and acrotelm thickness) most clearly distinguished ridges from hollows.

fourth component (explaining $12.5 \%$ of the total variance) revealed that higher EC values of the mire water were associated with lower $\mathrm{C}$ content of the plant tissue.

In general, measurement points on ridges had higher scores on both the first and the second PCA component (Figure 6). More detailed analysis of these scores revealed that the first component most clearly separated ridges from hollows (Figure 6). Most ridge points $(81 \%)$ exceeded the maximum score for hollows on the first component (Figure 6). Although less clear, the second component also enabled separation between ridges and hollows: $25 \%$ of the hollow points had a lower score than the minimum score for ridges (Figure 6). Also, $15 \%$ of the ridges exceeded the maximum score for hollows on the second component (Figure 6).

\section{Discussion}

\section{Patterns in Nutrients, Hydrology, and Hydrochemistry}

Our field survey in a maze-patterned peatland corroborated the hypothesis that underlying patterns in nutrients, hydrology, and hydrochemistry, together with the maze patterning of the peatland surface, could be induced by a combination of evapotranspiration-induced scale-dependent feedback and positive feedback (Table 1; Rietkerk and others 2004a, b; Eppinga and others in press). The measured diurnal dynamics in water table level clearly showed the effect of evapotranspiration on water table dynamics (Figure 4; on-line appendix B). During the measurement period, the water table under ridges was consistently lower than in the hollow in between. Inside the hollows the plant layer is very open and more or less floating, which results in a high hydraulic conductivity and a nearly horizontal water level. Therefore we expect that inside hollows, (potential) water flow diverges toward the ridges. This is supported by the observation that at night the water level consistently rose in both ridges, but lowered in the hollow in between (Figure 4; on-line appendix B). The observed water table dynamics suggest that differences in water table level between ridges and hollows were maintained because losses through evapotranspiration on ridges exceeded the inflow received from hollows during the day (on-line appendix B). Similar diurnal dynamics in water table level have been observed in other patterned wetland ecosystems, notably in a linearly patterned part of a Swedish bog (Kellner and Halldin 2002), in tree islands and surrounding sloughs in the Florida Everglades (Reed and Ross 2004), and in tree islands and the surrounding swamps in the Okavango Delta (McCarthy and others 1993). Islands or ridges having lower water tables than their surroundings, and this difference being maintained by higher evapotranspiration rates suggests that there is a continuous water flow from hollows to islands or ridges (Reed and Ross 2004), and thereby advective transport of nutrients and other solutes toward the islands or ridges (Wetzel and others 2005; Ross and others 2006).

The second component extracted with the PCA contained information on hydrochemistry, showing that nutrient concentrations in the mire water were associated with other, more conservative solutes such as sodium. This corroborates the notion that higher nutrient concentrations may be the result of higher evapotranspiration rates (McCarthy and others 1993; Bleuten 2001). Also we measured higher EC of mire water under ridges as compared to hollows. Because the water table in hollows is above the surface, there could be a more direct influence of precipitation on the chemical composition of the water (for example, Beltman and Rouwenhorst 1994), which could have contributed to the reported differences in mire water chemistry between ridges and hollows. However, nutrient concentration data in the mire water was in com- 
pliance with the independently gathered data on nutrient content in plant tissue (Figure 3), which suggests that the data on hydrochemistry, together with the other lines of data, can indeed be used to identify processes governing maze-pattern formation in our study site.

The occurrence of sharp boundaries between ridges and hollows (Figure 2) corroborated the occurrence of positive feedback in our study site. Moreover, the first component of the PCA revealed that both $\mathrm{N}$ and $\mathrm{P}$ content of plant tissue were negatively correlated with mire water temperature and positively correlated with distance to the water table (DWT). Because DWT indicates the thickness of the acrotelm, this positive correlation corroborates the notion that enhanced cumulative decomposition could also contribute to higher nutrient availability on ridges. This first component of the PCA most clearly separated ridges from hollows (Figure 6), which supports the view that peatland surface patterning may be amplified by positive feedback between net rate of peat formation and acrotelm thickness.

In this study we used $\mathrm{N}$ and $\mathrm{P}$ content of plant tissue as an indicator for nutrient availability. Although the nutrient content of plant tissue is also influenced by the amount of carbon fixation and dry matter production, $\mathrm{N}$ and $\mathrm{P}$ content has been suggested to be a reliable indicator for nutrient availability (de Wit 1963; Vermeer and Berendse 1983; Wassen and others 1995; U.S. EPA 2002). In particular $\mathrm{P}$ enrichment experiments commonly show that $\mathrm{P}$ content of plant tissue increases with $\mathrm{P}$ availability, regardless of the plant growth response (Solander 1983; Verhoeven and Schmitz 1991; Craft and others 1995). Increased P availability creates the possibility of luxury uptake, meaning that $\mathrm{P}$ is stored in vacuoles so that it can be used later (Davis 1991). For nitrogen, similar responses have been observed in $\mathrm{N}$ enrichment experiments (Shaver and Melillo 1984; Shaver and others 1998), although luxury uptake of $\mathrm{N}$ is not always observed (Verhoeven and Schmitz 1991). In this study, we compared differences between ridges and hollows by sampling the same plant species (C. lasiocarpa) during the same period within the same study site, meaning that these other factors that could possibly influence the nutrient content of plant tissue were kept as similar as possible.

Summarizing, we think that nutrient content of plant tissue is a reliable indicator for nutrient availability within our study site. Based on the different lines of field data presented in this paper, scale-dependent feedback and positive feedback synergistically driving maze-pattern formation seems a promising explanation for the maze-patterned peatland that was studied.

If peatland maze patterns were strongly associated with underlying patterns in nutrients, hydrology, and hydrochemistry, one would expect that these underlying patterns could be distinguished from peatlands without regular spatial patterning. Indeed, the measured patterns in nutrients, hydrology, and hydrochemistry in a maze-patterned peatland reported in this study are rather different from those reported for other peatland types. First, we found nutrient-richer conditions under elevated sites (ridges), instead of nutrient-poorer conditions (Couwenberg 2005, and references therein). Second, we found that the water flow was directed from hollows to ridges, instead of the other way around (Ivanov 1981; Belyea and Clymo 2001). Third, our hydrological measurements do not support observations that evapotranspiration rates are higher in hollows (Romanov 1968; Edom 2001; Belyea 2007).

On ridges, the presence of vascular plants may increase transpiration rates (Frankl and Schmeidl 2000), meaning that the evapotranspiration rate from ridges could exceed the potential open water evaporation rate (Souch and others 1998; Andersen and others 2005). On the other hand, lateral advection of warm air could induce a larger-scale oasis effect enhancing evaporation rates from hollows so that it also could exceed the potential open water evaporation rate (Price and Maloney 1994). Even without a clear difference in evapotranspiration rate between ridges and hollows, however, there could have been a net flux of water and nutrients from ridges to hollows during our study period. The reason for this is that our study was carried out in a period of net water loss (Figure 4; on-line appendix B). When the same amount of water is lost from ridges and hollows through evapotranspiration, the drop in water level is larger in the ridges than in the hollows because of their smaller effective porosity (Ivanov 1981; Belyea and Clymo 2001). It is important to note, however, that there is likely to be strong seasonal variation in the partitioning of evapotranspiration losses between evaporation and transpiration (Admiral and Lafleur 2007): especially in wet periods with precipitation excess (spring and fall), evaporation may be greatest. The differences in effective porosity, together with a higher evaporation rate in hollows, could therefore create a reversed net flux of water and nutrients (from ridges toward hollows) during spring and fall.

Summarizing, the diurnal dynamics of the water table as observed in this study (Figure 4) may substantially differ from other parts of the season. 
Nevertheless, the hypothesized mechanism driving pattern formation concerns the spatial redistribution of nutrients stimulating vascular plant growth on ridges and inhibiting vascular plant growth outside ridges. This implies that a net flux of water and nutrients only amplifies patterning during periods of vascular plant growth, in which nutrients are trapped by the vascular plants (on-line appendix A). During other parts of the season, this flux may be reversed, but this will not affect vascular plant growth and therefore it is not expected to exert a strong effect on the formation and development of maze patterning.

\section{Alternative Theories of Peatland Patterning}

Our hypothesis that scale-dependent feedback and positive feedback may synergistically drive mazepattern formation in peatlands contributes to a considerable body of theory on peatland pattern formation, which has mainly focused on the formation of linear patterns on slopes. It is interesting, however, to examine whether these two types of spatially regular patterning may be associated with similar mechanisms. Therefore, we will now discuss our field data with respect to theories and hypotheses on linear patterning as well.

For example, our data suggested that the ridges might dam the water upstream (Figure 5), caused by the lower hydraulic conductivity of the ridges. It has been hypothesized that differences in hydraulic conductivity between ridges and hollows can contribute to linear pattern formation in systems with unidirectional water flow (that is, on mire slopes, Foster and others 1983; Glaser 1992; Couwenberg 2005), but not maze-pattern formation on flat parts of mires (Couwenberg and Joosten 2005). Interestingly, we did find a larger-scale hydraulic gradient over the EW transect in our study site (Figure 5), which suggests a unidirectional water flow in a western direction. So, we could distinguish two types of water flow in our study site; smaller-scale water flow directed to the ridges that is possibly driven by evapotranspiration (Figure 4) and unidirectional water flow in the western direction on a regional scale (Figure 5). This regional gradient over the EW transect was $262 \times 10^{-7}$ (Figure 5). Although this regional gradient is similar to those seen in other patterned wetlands such as the Florida Everglades (Noe and others 2001), it was relatively weak as compared to the smaller-scale gradient over our three-point transect $\left(\sim 2500 \times 10^{-7}\right)$, which might explain the maze-pattern formation in our study site instead of linear patterning. With increasing slope it seems likely that the regional water flow would become the dominant process, leading to the formation of linear patterns. This notion stresses the importance of examining the effects of positive feedback, scale-dependent feedback, and hydraulic conductivity feedback simultaneously in future models on peatland pattern formation, because the data from our study suggested that these mechanisms might operate simultaneously in reality. If this is indeed the case, the importance of each mechanism for pattern formation will probably be dependent on site-specific conditions (for example, slope, vegetation types, climate).

There are also theories on peatland patterning that stress the importance of uplift of ridges by differential effects of frost heaving. Ridges remain frozen longer during the thaw season because the upper aerobic peat layer insulates the frost in ridges (Brown 1968; Moore and Bellamy 1974). The insulating capacity of ridges also became apparent in our study; during the relatively warm measurement period, water in the ridges was on average $5^{\circ} \mathrm{C}$ colder than the mire water in hollows (Table 2). Although differential effects of frost heaving cannot explain the formation of a spatially regular pattern, it may amplify existent spatial patterning in peatlands. The fact that we still encountered ice needles in the ridges at the end of July supports the idea that effects of frost heaving could be of secondary importance in peatland patterning.

Finally, some studies focus on the possible role of spring floods in pattern formation (Sakaguchi 1980; Seppäla and Koutaniemi 1985). During high water levels, as occurring with spring snowmelt, storage capacity in the hollows may be insufficient so that water can flow freely over the ridges (for example, Quinton and Roulet 1998). These conditions probably also occur in our study site, because of the snow pack that develops in winter in this part of Siberia (Semenova and Lapshina 2001). During the spring floods, slush and plant remains could be transported toward elevations on the mire surface, thereby amplifying the surface microtopography.

\section{Perspectives}

This discussion reveals that although the field measurements presented here corroborate the hypothesis of scale-dependent and positive feedbacks synergistically governing maze-pattern formation in peatlands, alternative hypotheses suggested to induce linear patterning cannot be ruled out. Previous theoretical predictions (Table 1) enabled an empirical test of our hypotheses by 
taking a "snapshot" of the ecosystem state. The alternative mechanisms described above, however, require longer-term observations to identify the role of processes that occur on a seasonal timescale. The developmental processes driving peatland patterning has been the field of much speculation, but little actual experimentation (Moore and Bellamy 1974; Belyea and Lancaster 2002). Therefore, we think that there are two promising avenues of future research.

First, a number of well-developed peatland simulation models exist (for example, Hilbert and others 2000; Belyea and Clymo 2001; Frolking and others 2001; Pastor and others 2002; Rietkerk and others 2004a; Couwenberg and Joosten 2005), but there is no model yet that incorporates the processes mentioned above. Such a combined model would enable the on and off switching of different processes. One of the strengths of such "modeling experiments" is that they can show the effect of processes and factors that are difficult to disentangle by field manipulations of patterned peatlands.

Second, the problem could be tackled with empirical experiments under controlled circumstances. Such an approach could be used to measure process rates (for example, evapotranspiration, hollow-ridge water flow, nutrient accumulation under ridges) and to identify causal relationships between these processes. This information is needed to assess the relative importance of the hypothesized feedbacks governing surface pattern formation in peatlands.

\section{ACKNOWLEDGMENTS}

We thank Helen de Waard, Gijs Nobbe, and Dineke van de Meent for help with the laboratory analyses, and Olga Pisarenko, Andrej Korolyuk, and Jan Hrupacék for assistance in the field. We would also like to thank Lisa Belyea, Peter de Ruiter, and two anonymous reviewers for many comments that improved the manuscript. Finally, we thank Johan van de Koppel for writing the R-script for bimodality. The research of MBE and MR is supported by a VIDI grant from the Research Council Earth and Life Sciences of the Netherlands Organization of Scientific Research (NWO-ALW) to MR.

\section{OPEN ACCESS}

This article is distributed under the terms of the Creative Commons Attribution Noncommercial License which permits any noncommercial use, distribution, and reproduction in any medium, provided the original author(s) and source are credited.

\section{REFERENCES}

Admiral SW, Lafleur PM. 2007. Partitioning of latent heat flux at a northern peatland. Aquat Bot 86:107-16.

Andersen HE, Hansen S, Jensen HE. 2005. Evapotranspiration from a riparian fen wetland. Nordic Hydrol 36:121-135.

Beltman B, Rouwenhorst TG. 1994. Impact on soil fertility by replacement of hydrologically different water types. In: Peters NE, Allan RJ, Tsirkunov VV, Eds. Hydrological, chemical and biological processes of transformation and transport of contaminants in aquatic environments (Proceedings of the Rostov-on-Don Symposium, May 1993). Wallingford: IAHS Press. pp 33-9.

Belyea LR. 2007. Climatic and topographic limits to the abundance of bog pools. Hydrol Process 21:675-87.

Belyea LR, Baird AJ. 2006. Beyond "the limits to peat bog growth": cross-scale feedback in peatland development. Ecol Monogr 76:299-322.

Belyea LR, Clymo RS. 2001. Feedback control of the rate of peat formation. Proceedings of the Royal Society of London B. pp 1315-21.

Belyea LR, Lancaster J. 2002. Inferring landscape dynamics of bog pools from scaling relationships and spatial patterns. J Ecol 90:223-34.

Belyea LR, Malmer N. 2004. Carbon sequestration in peatland: patterns and mechanisms of response to climate change. Glob Chang Biol 10:1043-52.

Bleuten W. 2001. Hydrochemistry. In: Bleuten W, Lapshina ED, Eds. Carbon storage and atmospheric exchange by West Siberian peatlands. Utrecht: Department of Physical Geography, Utrecht University pp 38-42.

Borren W, Bleuten W. 2006. Simulating Holocene carbon accumulation in a western Siberian watershed mire using a three-dimensional dynamic modeling approach. Water Resour Res 42:12413.

Brown RJE. 1968. Occurrence of permafrost in Canadian peatlands. In: Lafleur C, Butler J, Eds. Proceedings of the 3rd International Peat Congress, Quebec. Ottawa: National research council of Canada. pp 174-81.

Charman DJ. 2002. Peatlands and environmental change. New York: Wiley.

Couwenberg J. 2005. A simulation model of mire patterning-revisited. Ecography 28:653-61.

Couwenberg J, Joosten H. 2005. Self-organization in raised bog patterning: the origin of microtope zonation and mesotope diversity. J Ecol 93:1238-48.

Craft CB, Vymazal J, Richardson CJ. 1995. Response of Everglades plant communities to nitrogen and phosphorus additions. Wetlands 15:258-71.

Davis SM. 1991. Growth, decomposition and nutrient retention of Cladium jamaicense Crantz and Typha domingensis Pers. in the Florida Everglades. Aquat Bot 40:203-24.

de Wit CT, Dijkshoorn W, Noggle JG. 1963. Ionic balance and growth of plants. Verslagen van Landbouwkundige Onderzoeken 69.15. Wageningen: Pudoc.

Edom F. 2001. Moorlandschaften aus hydrologischer Sicht (chorische Betrachtung). In: Succow M, Joosten H, Eds. Landschaftsökologische Moorkunde. Stuttgart: Schweizerbart. pp 185-225.

Eppinga MB, Rietkerk M, Wassen MJ, De Ruiter PC. in press. Linking habitat modification to catastrophic shifts and vege- 
tation patterns in bogs. Plant Ecol. On-line available: DOI 10.1007/s11258-007-9309-6.

Foster DR, King GA, Glaser PH, Wright HE Jr. 1983. Origin of string patterns in boreal peatlands. Nature 306:256-8.

Frankl R, Schmeidl H. 2000. Vegetation change in a South German raised bog. Ecosystem engineering by plant species, vegetation switch or ecosystem level feedback mechanisms? Flora 195:267-76.

Frolking S, Roulet NT, Moore TR, Richard PJH, Lavoie M, Muller SD. 2001. Modelling northern peatland decomposition and peat accumulation. Ecosystems 4:479-98.

Glaser PH. 1992. Ecological development of patterned peatlands. In: Wright HE Jr, Coffin BA, Aaseng NE, Eds. The patterned peatlands of Minnesota. Minneapolis: University of Minnesota press pp 27-43.

Hilbert DW, Roulet N, Moore T. 2000. Modelling and analysis of peatlands as dynamical systems. J Ecol 88:230-42.

Holden J, Burt TP. 2003. Hydrological studies on blanket peat: the significance of the acrotelm-catotelm model. J Ecol 91:86-102.

Ivanov KE. 1981. Water movement in Mirelands (Vodoobmen v bolotnykh landshaftakh). Translated by Thomson A, Ingram HAP. London: Academic Press.

Kellner E, Halldin S. 2002. Water budget and surface-layer water storage in a Sphagnum bog in central Sweden. Hydrol Process $16: 87-103$

Lapshina ED, Mouldiyarov EY, Vasiliev SV. 2001a. Analyses of key area studies. In: Bleuten W, Lapshina ED, Eds. Carbon storage and atmospheric exchange by West Siberian peatlands. Utrecht: Department of Physical Geography, Utrecht University pp 23-37.

Lapshina ED, Polgova NN, Mouldiyarov EY. 2001b. Pattern of development and carbon accumulation in homogeneous Sphagnum fuscum-peat deposit on the south of West Siberia. In: Vasiliev SV, Titlyanova AA, Velichko AA, Eds. West Siberian peatlands and carbon cycle: past and present. Proceedings of the International Field Symposium (Noyabirsk, August 18-22, 2001). Novosibirsk: Agenstvo Sibprint. pp 101-104.

Levin SA. 1998. Ecosystems and the biosphere as complex adaptive systems. Ecosystems 1:431-6.

McCarthy TS, Ellery WN, Ellery K. 1993. Vegetation-induced, subsurface precipitation of carbonate as an aggradational process in the permanent swamps of the Okavango (delta) fan, Botswana. Chem Geol 107:111-31.

Moore PD, Bellamy DJ. 1974. Peatlands. London: Elek Science.

Noe GB, Childers DL, Jones RD. 2001. Phosphorus biogeochemistry and the impact of phosphorus enrichment: why is the Everglades so unique? Ecosystems 4:603-24.

Pastor J, Peckham B, Bridgham S, Weltzin J, Chen J. 2002. Plant community dynamics, nutrient cycling, and alternative stable equilibria in peatlands. Am Nat 160:553-68.

Price JS, Moloney DA. 1994. Hydrology of a patterned bog-fen complex. Nordic Hydrol 25:313-30.

Quinton WL, Roulet NT. 1998. Spring and summer runoff hydrology of a subarctic patterned wetland. Arct Alp Res 30:285-94.

Reed DL, Ross MS. 2004. Hydrological variation among and within tree islands of Shark Slough. In: Ross MS, Jones DT, Eds. Tree islands in the Shark Slough landscape: interactions of vegetation, hydrology and soils. Miami: Southeast Environmental Research Center Florida International Univ. pp 5-17.
Rietkerk M, Dekker SC, Wassen MJ, Verkroost AWM, Bierkens MFP. 2004. A putative mechanism for bog patterning. Am Nat 163:699-708.

Rietkerk M, Dekker SC, De Ruiter PC, Van de Koppel J. 2004. Self-organized patchiness and catastrophic shifts in ecosystems. Science 305:1926-9.

Romanov VV. 1968. Hydrophysics of bogs. Israel Program for Scientific Translations.

Ross MS, Mitchell-Bruker S, Sah JP, Stothoff S, Ruiz PL, Reed DL, Jayachandran K, Coultas CL. 2006. Interaction of hydrology and nutrient limitation in the Ridge and Slough landscape of the southern Everglades. Hydrobiologia 569:37-59.

Sakaguchi Y. 1980. On the genesis of banks and hollows in peat bogs: an explanation by a thatch line theory. Bulletin of the Department of Geography University of Tokyo 12:35-58.

Semenova NM, Lapshina ED. 2001. Description of the West Siberian plain. In: Bleuten W, Lapshina ED, Eds. Carbon storage and atmospheric exchange by West Siberian peatlands. Utrecht: Department of Physical Geography, Utrecht University pp 10-22.

Seppäla M, Koutaniemi L. 1985. Formation of a string and pool topography as expressed by morphology, stratigraphy and current processes on a mire in Kuusamo, Finland. Boreas 14:287-309.

Shaver GR, Johnson LC, Cades DH, Murray G, Laundre JA, Rastetter EB, Nadelhoffer KJ, Giblin AE. 1998. Biomass and $\mathrm{CO}_{2}$ flux in wet sedge tundras: responses to nutrients, temperature and light. Ecol Monogr 68:75-97.

Shaver GR, Melillo JM. 1984. Nutrient budgets of marsh plants: efficiency concepts and relation to availability. Ecology 65:1491-1510.

Sjörs H. 1983. Mires of Sweden. In: Gore AJP, Ed. Ecosystems of the world 4B. Mires: swamps, bog, fen and moor. Amsterdam: Elsevier pp 69-94.

Sokal RR, Rohlf FJ. 1995. Biometry. 3rd ed. New York: WH Freeman and Company.

Solander D. 1983. Biomass and shoot production of Carex rostrata and Equisetum fluviatile in unfertilized and fertilized subarctic lakes. Aquat Bot 15:349-66.

Souch C, Susan C, Grimmond B, Wolfe CP. 1998. Evapotranspiration rates from wetlands with different disturbance histories: Indiana Dunes National Lakeshore. Wetlands 18:21629.

Swanson DK, Grigal DF. 1988. A simulation model of mire patterning. Oikos 53:309-14.

U.S. EPA. 2002. Methods for evaluating wetland condition: vegetation-based indicators of wetland nutrient enrichment. Washington DC: Office of Water, U.S. Environmental Protection Agency.

Van de Koppel J, Herman PMJ, Thoolen P, Heip CHR. 2001. Do alternate stable states occur in natural ecosystems? Evidence from a tidal flat. Ecology 82:3449-61.

Vasiliev SV, Kosykh NP, Mironycheva-Tokareva NP. 2001. Actual carbon accumulation by crop measurement. In: Bleuten W, Lapshina ED, Eds. Carbon storage and atmospheric exchange by West Siberian peatlands. Utrecht: Department of Physical Geography, Utrecht University pp 87-96.

Verhoeven JTA, Schmitz MB. 1991. Control of plant growth by nitrogen and phosphorus in mesotrophic fens. Biogeochemistry 12:135-148. 
Vermeer JG, Berendse F. 1983. The relationship between nutrient availability, shoot biomass and species richness in grassland and wetland communities. Vegetatio 53:121-6.

Wallén B. 1987. Growth pattern and distribution of biomass of Calluna vulgaris on an ombrotrophic peat bog. Holarctic Ecol 10:73-9.

Wallén B, Falkengren-Gerup U, Malmer N. 1988. Biomass, productivity and relative rate of photosynthesis of Sphagnum at different water levels. Holarctic Ecol 11:70-6.

Wassen MJ, Joosten JHJ. 1996. In search of a hydrological explanation for vegetation changes along a fen gradient in the Biebrza Upper Basin (Poland). Vegetatio 124:191-209.
Wassen MJ, Olde Venterink HGM, de Swart EOAM. 1995. Nutrient concentrations in mire vegetation as a measure of nutrient limitation in mire ecosystems. J Veg Sci 6:5-16.

Wassen MJ, Olde Venterink HGM, Lapshina ED, Tanneberger F. 2005. Endangered plants persist under phosphorus limitation. Nature 437:547-50.

Wetzel PR, Van der Valk AG, Newman S, Gawlik DE, Troxler Gann T, Coronado-Molina CA, Childers DL, Sklar FH. 2005. Maintaining tree islands in the Everglades: nutrient redistribution is the key. Front Ecol Environ 3:370-6. 